\title{
YAC ТЕПЕРІШНІЙ
}

DOI: $10.33608 / 0236-1477.2021 .04 .76-96$

УАК 821.161.2: 82-1: «200/201»

Анатолій МОЙСІЄНКО, доктор філологічних наук, професор Київський національний університет імені Тараса Шевченка бульвар Тараса Шевченка, 14, Київ, 01601 e-mail:anmoj@ukr.net ORCID: https://orcid.org/0000-0002-7856-2746

\section{МИСТЕЦЬКИЙ СИНТЕЗ У ШАХОСОНЕТІ}

Стаття присвячена одному з візуальних видів синкретичної поетичної творчості - mахопоезії. На матеріалі збірок В. Капусти «Картатий материк» та «Негарантована мігрантіана» проаналізовано шахосонетний доробок поета, який уписав нову сторінку в українську візуалістику, запропонувавши рівноправне поєднання чітко структурованої літературної форми із шаховою задачею. Звернено увагу на трансформачійні особливості сонетного рядка, що прочитується паліндромно-панторимно. Панторима служить версифікаційною $i$ композичійною основою шахового вінка сонетів «Рокірування. Зір гербарій», який аналізується з урахуванням транспозиційності тих чи тих характеристик на шахово-композиційне підгрунтя.

Ключові слова: шахопоезія, шахосонет, паліндромний сонет, панторимний вінок шахосонетів, оказіоналізм.

Українська візуальна поезія, що як цілісне мистецьке явище постає ще з доби бароко (I. Вемичковський, С. БеринАа, М. Аовгалевський та ін.), плідного розвитку набуває у XX ст., на його початку, зокрема у творчості футуристів (М. Семенко, Г. Шкурупій, О. САісаренко та ін.) і особливо - наприкінці століття з виникненням мітературних груп « АуГоСаА», «Геракліт», «НіМБ зорослова» (наукове і мистецьке братство), і виходом у 1998-му і 1999му роках альманаху «Зрима рима», що означувався як

Ц и т у в а н н я: Мойсієнко А. Мистецький синтез у шахосонеті // Сиово i Чac. 2021. № 4 (718). С. 76-96. https://doi.org/10.33608/0236-1477.2021. 04.76-96 
«мітопис творчих подій в українській візуацьній поезї та у мистецтві поезографіки».

XXI століття відкриває нові обрії поетичної візуалістики. Синкретичний (вербацьно-зображацьний) характер вірша знаходить дедалі ширшу зацікавленість у мистецьких, мітературно-критичних колах. Про зоровий вірш, його особливості, функціонацьну спромогу пишуть як самі автори, так і відомі дослідники $[22 ; 16 ; 19 ; 23 ; 17 ; 14 ; 13]$.

Можна сказати, що зорова поезія як напрямок синтетичної творчості на українських мистецьких просторах набуває повноти художньої структури і надає ій певної завершеності зі вциттям шахопоетичного струменя $[15 ; 11 ; 8 ; 12: 2,582 ; 9 ; 18]$. Незважаючи на відносну молодість,

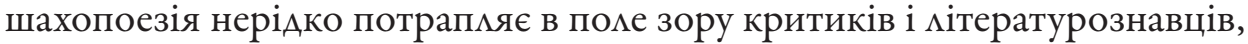
у ній ведуться цікаві пошуки тем, версифікаційних і зображувальних засобів через розвиток різних жанрів. Говорячи про явище шахопоезіі, М. Жулинський зауважує: «У поетичний текст “вживлюються” шахові ходи - ці своєрідні коди, завдяки яким фігури оживають і починають Аіяти» $[4,6]$. Відбувається зіткнення двох мов.

Прикметним фактом $є$ поява шахосонета - рівноправного симбіозу чітко структурованої Аітературної форми із шаховою задачею. Перспективність цього зорожанру вельми переконииво засвідчица сонетна збірка Віктора Капусти «Картатий материк» [8]. Ії̈ автор - мітератор і водночас гросмейстер України (майстер спорту міжнародного кмасу) із шахової композиції. Спираючись на образне слово, він шукає смислові зв'язки з мистецькими теренами шахової гри, на яких виникають то чорно-білі витончені цінії діаграмних естампів, то чарів иві відзвуки застиглої музики, то виконані з античною достеменністю пластичні різьблення, то розмальовки в стилі фолькцорної орнаментики, то розмай геометричних абстракцій, нарешті - мізансцени непередбачуваних театрацьних вистав, розіграних дерев'яними фігурками чи неозначеними живими істотами на шахівниці читацької уяви. Що потрібно Амя осягнення пропонованого матеріалу віА шанувальника шахопоезії? Бажання вчитуватися i, зрозуміло, хоч би поверхове знайомство з правилами старовинної гри. Без цього годі зарядитися енергетикою мистецьких асоціацій.

У $і$ ірико-іронічній передмові «Пробудження сонетошахівниці» автор «Картатого материка» прагне з'ясувати деякі творчі засади:

Чому шахосонети? Примха інтуїції. Словесна енергія терцетів і катренів, мабуть, наймегше синхронізується з три- і чотириходовими шаховими сюжетами. Хоча будь-які алгебраїчні перевірки гармонії мають вторинне значення. Найбільше хотілося допетрати, куди веде формула, запропонована молодим Набоковим: «...На доске составим я сонет» $[8,4]$.

Реацізація творчої установки з уточненням художньої позиції шахопоета триває не один рік. У наступній книжці віршів В. Капусти 
(«Негарантована мігрантіана» [10]) частина шахосонетів зазнаца суттєвого авторського редагування, що певною мірою відкоригувало і його інтерпретацію «набоковської формули». Читаймо:

\section{ГЕОМЕТРІЯ РИТМУ}

Сумує симфонічний оркестр без голосу трикутника-трензеля

Невільник геометрії із грат

ВіАлив тривку мелодію трикутно,

Иуною тренземя закрався смутно

У підмурівка мріяний квадрат.

Із форми звуку - у цейтнот розраА,

Що в піраміді-метрономі чутно.

Чи Тутмес ритму проведе остудно

Під знаком Нефертіті в місто втрат?

Квадрат — катрену, три кути - терцету.

Несімо сумніви у храм сонета!

На паперті сердець мінор - з очима.

О, воле сповіді! Захочу - рушу...

Хотіннями рокірувалась рима,

А трензель відзвуком вгамує душу.

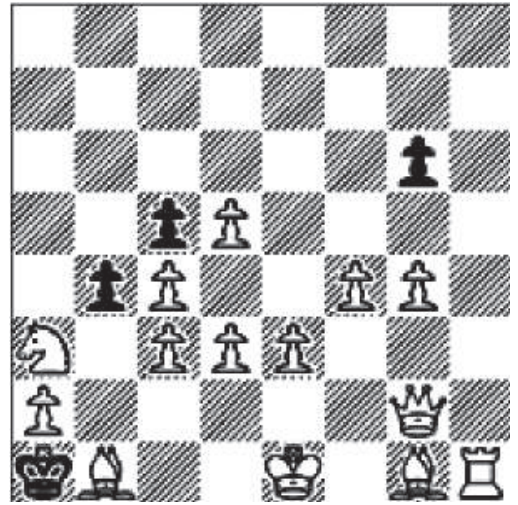

\#3

$14+4$

1.g5, цугцванг! b:a3 2.Ch2, цугцванг! Кр:b1 3.0-0\#, 1...b3 2. Th2! b2 3.Ф:b2\#, 1...b:c3 2.Фh2, цугцванг! c2 3.Фh8\#. [10, обкладинка]. Рухливий фігурний трикутник, утворений на діаграмі ферзем, турою і слоном та вписаний у квадрат hlg1g2h 2 на краю шахівниці, подібно терцету шукає Аогічного зАиття із сонетним катреном, прагне висповідатися в слові. Його «геометрична» мова рветься до вербальної потуги через історичні, художні, містичні ремінісценції «Із форми звуку - у цейтнот розраА, / Що в піраміАі-метрономі чутно». Моментально-калейдоскопічні 
сонетні картини метафорично заглиблюються щонайменше до давньоєгипетської доби. Синтезована образність, як добре вино в сполучених посудинах, перетікає віА діаграми до тексту і навпаки, вихлюпуючись у потаємно-сакральний глиб досліджуваних просторів: «Несімо сумніви у храм сонета!». Цікавий поворот у «формулі», яку запропонував майже століття тому Володимир Набоков - російсько-американський письменник, завзятий ентомолог і шаховий композитор в одній персоні.

Геометричні мотиви набувають особливої рельєфності в шахосонеті «Урок проблеміста» (довільний переклаА сонета Набокова) [8, 14-15; $10,85]$. Иого Аіаграмна частина на Аругих ходах послідовно перетворює конфігурацію квартету білих пішаків на квадрат, паралелограм і трикутник. А на третіх ходах кожний пішак із динамічною промовистістю накреслює перевернутий трикутник. Постежмо за геометричною грою на сонетній шахівниці:

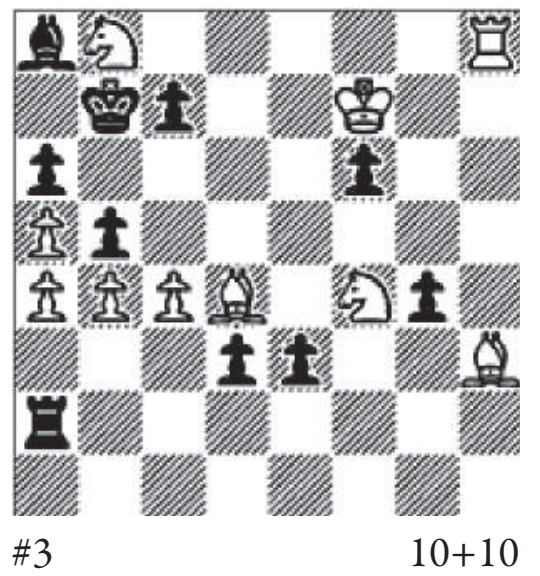

Іиюзорна гра: 1...g3 2.Cc8+ Kp:b8 3.Сa6\#!. Розв'язок: 1.Ке6! із загрозою: 2.c:b5! 3.b:a6\#!, 2...c5 3.b:c6\#, en passant(e.p.)!, 2...a:b5 a6\#!; 1...b:c4 (b:a4) 2.b5! 3.b:a6\#!, 2...c5 3.b:c6\# e.p.!, 2...a:b5 a6\#!; 1... Tc2 2.a:b5! 3.b:a6\#!, 2...c5 3.b:c6\# e.p.!, 2...a:b5 a6\#!; 1...c5 2.b:c5 3.c6\#; 1...T:a4 2.Cg2+ c6 3.C:c6\#.

Візуальна частина твору прокцадає шлях до читацького співпереживання по-молодому наївною символікою, яка йде віА інтерпретації набоковського сонета. На діаграмі чітко проглядається вибудувана білими пішаками стилізована матинська мітера $L$, із якої, наприклаА, починається англійське слово love (“любов”), що може асоціюватися Аля компетентного читача і з закоханістю письменника в його молоду Аружину, і з його Авомовністю в мітературній роботі. А втім, кожен має право на свою інтерпретацію побаченого і прочитаного: 
Я не писав законного сонета

Ао розсвіту піА солов їний спів, -

Торкаючись то тур, то пішаків,

Придумував задачу в миті кету.

I в ній вмістив віА тебе по секрету

I нашу ніч, і невимовність слів,

I зоряний розАив поміж світів,

I тополину тінь, і дар поета.
А корифеї шахових кав'ярень

I Фікідор, який вночі примаривсь, -

Гадаю, сприймуть цих ходів ажури

Й побачать: світло місяця, планет;

Моє кохання чисте, без зажури;

На шахівниці складений сонет.

Беручи в задачі пішаків en passant, тобто неординарним способом на проход $i$, ліричний герой наче нашіптує нам із нічної напівтемряви, що керовані ним піхотинці й «корифеї шахових кав’ярень», не наважуючись перервати безтурботний сон молодої жінки, мовчазними тінями проходять через поетову кімнату просто в сонетні рядки.

Цілісність поетичного тексту і змісту шахової задачі - пліА подвоєного натхнення. Можливо, його природа втаємничена ще більше, ніж творча іскра в пісні барда, яка синхронно спрямовує вірш та мелодію до меломанів від одного збентеженого серця. Проте в поціновувача шахопоетичного твору $є$ можливість без поспіху перейти від читання тексту до перегляду шахової задачі, а потім вернутися вспак, осмислюючи явні й приховані паралемі, протягуючи невидимі ниті між ними. Автор «Картатого материка», розмірковуючи про творче збентеження та перший поштовх до Аії поета-шахіста, у передмові стверджує: «Бентега мишень оманливий орієнтир. Що за нею?». I Аалі згаАує про знайомство з книжечкою «Шахопоезія» автора цих рядків, що тоді вів шаховий відАіл у газеті «Українське слово», на адресу якої наприкінці 1998 р. й надіслав миста чорнобильський журналіст В. Капуста із власним сонетом і задачею як відгук на одну з опублікованих в «Українському слові» шахопоезій зі згаданої книжечки. Саме тоді з мегкої руки «Українського слова» й було оприлюднено перший шахосонет [11] в українській зоропоезіі. ОАнак автор, працюючи над ним, опублікував іще дві версії $[8,34-35 ; 10,73]$. Прагнучи зблизити розмай слова із шаховим космосом, він надалі не раз доопрацьовував надруковані тексти та пов'язані з ними задачі. Ось остання варіація першосонета з позначеною наскрізною вертикамлю «сонетні тіні зір»:

\section{COME IN}

Необережність - доня САіпоти.

«Чи знаєш, звідки камінь на підАОні?» -

«Із роздоріж. ЗажАи, спечеш АолоНі! » -

«В підмурок — камінь! Годі!» — кажЕш ти.

На ньому - три путі чи три поТи.

Напра..., налі... і прямо... БезкомоНні.

Стинаються у путовІм агоні. 
А кінь?.. Об”ївся часу блекоТи.

Наріжний камінь, родом з роздорІж,

Не здержить розбріА прохіАНих піАків.

Крізь комин вирізає тяги нІж

Тріскучі піктограми яЗиків...

І репнув камінь у вогні. АмІнь.

ШкваРчала мова язиків: «Come in».

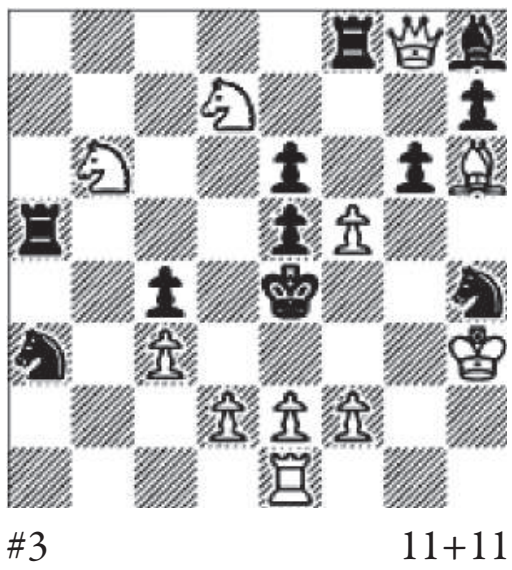

1...Kp:f5 2.e4\#; 1.Tg1! із загрозою: 2.Tg4+ Kp:f5 3.e4\#; 1...T:f5 2. $\Phi$ a8+! T:a8/Td5 3.Kc5\#; 1...e:f5 2.Ф:c4+! K:c43.d3\#; 1...g:f5 2.Фg2+! K:g2 3.f3\#, 2...Kf3 3.. :f3\#.

Мені, знайомому з кожною з варіацій такого «саморуху» твору, неважко стверджувати, що остання версія зміцнила образну фактуру шахосонета. Текст, здається, остаточно взяв у полон шахову діаграму, озвучуючи ходи словесно-музичним суголоссям. КАючову мепту в збагачення змісту вносить англомовний заголовок, що ввів шахосонет у сферу міжмовної паронімічної атракції та омонімії. Слова камінь, комин, амінь підкреслено посилюють свою знаковість на тлі схожого за звучанням ангмійського словосполучення come in («кам ін», тобто 'увійдims'), яке виростає Ао образного рівня. Причому автор свідомо «тримає в прикупі» неназваним слово камін, на яке недвозначно вказують «тріскучі піктограми язиків», і неодмінно розраховує на читацьке розуміння. Цей же прийом фонічної організації з нерозкодованою атракцією застосовано в заголовках шахосонетів «Пара фраз» (відсилання до парафраз) $[8,26]$ і «Хира мантія води» (хіромантія) [8, 70], у прикінцевих рядках диптиха «Комп'ютерний гендер»: «Смішних чекань облізла позолота... / Чи справдились?.. Того шум ер не знав» (жумер). [10, 79]. У першій частині триптиха «На перехресті трьох склепінь» $[10,66]$ читачеві запропоновано розкодовувати зразу кілька атракцій: «За стигмами верлібри ката строф / Бредуть, бредуть, бредуть як стій по кругу...» (катастроф); 
«Страхує в храмові ману ментальну / Тендітність...» (монументальну). А слово віра, хоч і згадане в тексті один раз як професійне слівце будівничих храму (команда підняти вантаж), неминуче відлунює глибинносакрацьним: «Оговтаються бані, і настира / Розбудить кревним будівничим: “Вipa!” ».

Міжмовна атракція стає важливим чинником поетового іАіостилю. У назві циклу «Тетраптих посhеssних імпресій» [10, 80-83] англійське chess («чес», тобто 'шахи') апмікаційно вклеїлося у Авомовну комбінацію почесних. У заголовку триптиха «Набоков-street» англійське street ('вуличя') звучить як «стріт», тобто близько до українського Аієслова стріти; отже, на поетичній вулиці Набокова обіцяна і стріча з ним самим [8, 12-17].

Шахосонети В. Капусти мобілізовують читача на формування власного сприйняття вербальних і шахових текстів. Часом це нелегке читання i, звичайно ж, не побіжне споглядання. Навіть коли автор робить ті чи ті підказки, не слід розслаблятися, бо можна пройти мимо важливої, Аалеко не шахової детаці, що завуацьована в розрахунку на читацьку пицьність та дотепність. Згаданий уже сонет «Пара фраз» із підзаголовком-підтекстом «Росяну мову твоїх ступень підсушує санскрит мистя» не становить винятку [8, 26-27]. Вчитаймось у його Аіричні рядки:

ЧаАра мегкої павутини

Твоє чоло оповила...

I $\Lambda$ іто бабине в чадрі

Синь неба. Явір. Світ — гала.

Тривога птаха-сиротини,

Павук навперехрест коранив.

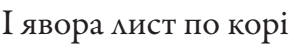

Торкнувши скроню яворини,

ВАетіка в корінь стовбула.

Пробрався - павука таранив.

Була надії мить мала,

Кров яворилась, запеклась.

Що явір чує духу впини...

Чадру розпкутати нам зась.

Текст суголосно переходить у задачу з пішаковою павутиною-чадрою:

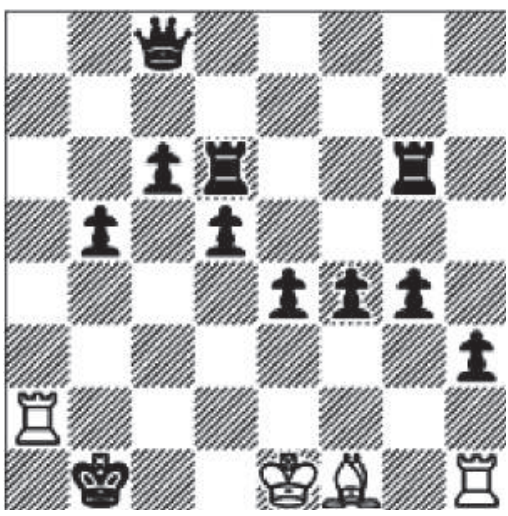


1.Tah2! зз загрозою: 2.Cd3 +! е:d3 3.0-0\#; 1...Tde6 2.Cc4! d:c4 3.00\#; 1...Фe6 2.C:b5! c:b5 3.0-0\#; 1...Tge6 2.C:h3! g:h3 3.0-0\#.

Чому «Пара фраз»? Бо фактично маємо Аіалог. Аругого учасника, а точніше учасницю, поетичного перегуку знаходимо в книжці «Остроконечный круг» Аюбові Никифорової: «Чадрою мёгкой паутины / Опутано моё мицо. / И мыслей зыбкое кольцо / В плену у грусти беспричинной» $[20,40]$. Метафорична чадра павутинкою споцучица Аві цюдські стихії в неспокійному світі. I одній, і Аругій раптом передалася «тривога птаха-сиротини», після чого вже неможииво із замикуванням сприймати мацьовничі пейзажі. За порухом кожної травинки, за кожним повівом меготу вчувається щось більше, ніж ностальгійні переживання переходу земного Аіта в осінь. Читач зі швидкістю падіння

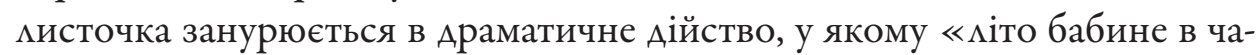
Арі / Павук навперехрест коранив. / I явора мист по корі / Пробрався павука таранив . Поява кривавиці, що явориться, напряму навертає до пристрасного кипіння соціуму. І вже фраза «навперехрест коранив» не так метафора з відіменниковим дієсловом-оказіоналізмом коранив (від Корану), як скалка не розв'язаних мюдством проблем, щонайперше в царині духовності й віри. Аіаграма-гравюра Аише загострює подібні віАчуття. Пішакова чадра не просто зависла в повітрі, а розкраяла зазублинами світ шахівниці на антагоністичні частини: перед нею - білі фігури, за нею вгорі - відмежовані чорні. Символи жіночого і чоловічого начац? Непримиренні сими на планеті Земля? Релігійні суперечності? Космічні спацахи добра і зма?.. На жаць, «чадру розплутати нам зась», що стає своєрідним парафразом «Пари фраз».

Можна помітити, що в розв'язках низки сонетних задач наявне рокірування. По-своєму унікальний шаховий хіА, коли за певних умов дозвомено пересувати зразу дві одноколірні фігури - короля і туру. У нотації коротке рокірування позначають Авома нумями, а довге - трьома: 0-0; 0-0-0. Етимологічний шлях в Україну терміни рокірування, рокіровка, рокіруватися почали за перським посередництвом віА rokb ('віз') [3, 118]. Проте вони суголосні й поширеному поняттю рок ('доля'), яке, прийшовши до нас із давньогрецької і старослов'янської, мандрує в одязі мексем рокований, рокувати, пророк, зарок. Цю близькість мінгвістичних Ажерел використовує шахосонетяр, поклавшись інтуїцією на міжмовношахову паронімічну атракцію. Рокірування як наслідок ускладненого синтезу рухів шахових фігур у його трактуванні перетворюється на образ переплетених доль - і мюдських, і космічних. Автор уводить його навіть у заголовок вінка сонетів («Рокірування. Зір гербарій»). Маленька космічно-шахова цитата звідти: «Рокірувань короткі замикання / Парад планетам гасять спозарання» $[10,99]$. ОАнак розцога розмова про вінок іще попереду. У сонеті «У затінку Аюбові» цей образ подано в 
Аосить оптимістичній тонацьності: «У світлотіні - шахове наймення. / Відтоді біг зигзагом долі кінь... / I нас рокірував на непокинь / За дваАцять Аев’ ять Анів Ао рівнодення $[8,20]$.

У шахосонеті «0-вацьс» $[8,8-9]$ елемент рокірування вжито як шаховий знак (0-0, 0-0-0) не мише в нотації розв'язку до діаграми, а й у самому тексті:

О! Нас давно не видко на кону.

Микола Зеров

Коромю! Не бублик - пігулки Аля гуль...

Навколо корони розвидниться в Торі:

У вені Буття мейкемії докори

Червоні тільця заокруглить у 0 .

Крізь ВихіА-піАситок наточить з аорти Покути, мов меду з розбитої борті.

А в Числах - загнуздують пульси півкуль:

$0-0$.

I коА рокіровки, й імунні розори

Повторозаконню повернуть повтори.

І турочки вальс... Коромя постамбуль

У кавовий шепіт обротьки : «I'm sorry...»

Зінфантило вашу інфарктність оА гуль?

$0-0-0$...

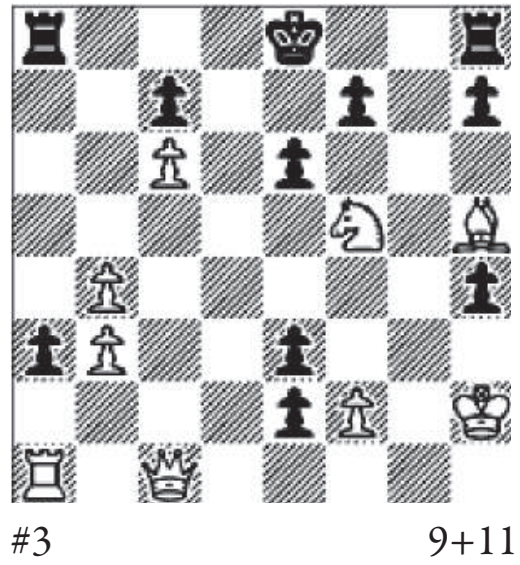

І юзорна гра: 1...0-0-0 2.Ф:a3 Кpb8 3.Фа8\#, 1...0-0 2.Фg1+ Kph8 3. Фg7\#. Хибний сліА: 1.Ф:е3 ? із загрозою: 2.Ф: е6+, 1...0-0-0 2.Фа7 Т d8 3.Фa8 \#, 1...0-0 2.Фg5+ Kph8 3.Фg7\#, але 1...е1Ф! Розв'язок: 1.Фс4! із загрозою: 2. $Ф: \mathrm{e} 6+\mathrm{Kpf8} 3 . \Phi: f 7 \#, 2 . . \mathrm{Kpd} 8$ 3.Фd7\#; 1...0-0-0 2.Фa6+ Kpb8 3.Фb7 \#; 1...0-0 2.Фg4+ Kph8 3.Фg7\#; 1...Kpf8 2.Фc5+ Kpg8 3.Tg1 \#, 2... Kpe8 3.Фe7 \#; 1...Kpd8 2.Фd4 + Kpe8, Kpc8 3.Фh8\#. 
Тут ходи-рокірування подані, фактично, у двох тмумаченнях. Користуючись графічною близькістю цифри «0» і букви «О», автор, можна Аумати, віААає прочитання заголовка на волю читача - при трактуванні як «Нуль-вальс» чи як «О-вальс» (відсилання до слова овал). Біблійні мотиви, позначені назвами-віхами частин П'ятикнижжя, у шахосонеті переплетені з іронічним ставленням до короля (шахового? з якогось казкового королівства?), котрому «Навколо корони розвидниться в Toрі: / У вені Буття мейкемії Аокори / Червоні тільця заокруглять у $0 \gg$. Аалі нотацію рокірувань уживлено прямо у віршований текст: «Крізь ВихіА-піАситок наточить з аорти / Покути, мов меду з розбитої борті. / А в Числах - загнуздують пульси півкуль: / 0-0.». Старого хворобливого гультяя, що не знає ні в чому міри, важко зупинити, але: «I турочки вальс... Короля постамбуль / У кавовий шепіт обротьки: “I’m sorry...” / Зінфантимо вашу інфарктність оА гуль? / 0-0-0...». Грайливість уявного вальсування на раз-два-три граціозно увиразнює чотиристоповий амфібрахій, який у цьому сонеті прийшов на зміну традиційному ямбу. Текст рясніє авторськими новотворами, вирощеними, мов екзорослини, на танцювальному паркеті шахівниці. Із турочкою-Ажезвою вальсує Аієслово постамбуль, утворене від назви колишньої столиці Туреччини. Ще одне відіменникове дієслово - зінфантило (віА інфанта). Ао нього сліАом Аодано відверто гротескову вашу інфарктність.

Авторове прагнення оновлювати індивідуалізованою мексикою сонетні тексти не епізодичне. Кілька витягів з інших творів: нев'янь-любов $[10,83]$, неботиньк $[8,20]$, небогладь $[8,30]$, однолап'я («Чапменя чатує в однолап̈̈») [8, 67], хамелеонити («Хамелеонить шахіницю тка») [10, 84], правослів'я («Правослів'я в православ'ї») [8, 61], будень-непробудень $[8,53]$. У сонеті «Розп'яття» $[8,44 ; 10,67]$ зібрано цімий букетик скмадних мексем, утворених у комбінації з компонентом перв (первонепоборність, первогорність, первоз'ява), і навіть смово-рядок наперводобровістеспасотворність. Поряд із цим не загубилися недозачину сотворикумир і більмує («Голгофи еверест більмує зір»). Останній приклаА має авторське продовження ще й за межами шахопоезії в «Білінгві навиліт»: «У шафі підбільмовує словник» $[10,5]$. Варто окремо звернутися до сонета «Позолоти ісусальність» $[10,66]$ і продовжити раніше цитовані рядки: «Страхує в храмові ману ментальну / Тендітність позолоти ісусальна». За законами паронімічної атракції та творчим посередництвом шахопоета приєднання мише однієї Аітери («і») наблизило слово сусальний до Господнього імені.

Словотворення притаманне й перекладацьким студіям автора. Інтерпретуючи аргентинських поетів Х. А. Борхеса та О. А. Мейлана [24, 56-61] за книжкою шахосонетів «64. Повторення чисел» (Буенос-Айрес, 2006), він знаходить поетичні відповідники іспаномовним текстам, у 
яких свій мінгвістичний менталітет. Якщо з перекладом пішака з вірша Борхеса («С аабкий король за хитрим пішаком / Чаїться») немає жоАних проблем, то як бути у випадку з Мейлановим текстом, де пішак перетворився на королеву (не ферзя)? Виникає Авомовний гендерний конфлікт, що його в перекладі погашено досить просто: «Проте із-піА стола пимьнує блазень, / Як герцог-офіцер в кукавім тості / Триножить погляду небесну синь / Нової королеви з пішакинь». У поетичних інтерпретаціях В. Капусти замість пішака можна вздріти оригінацьне (зі зниженим забарвценням) недобігура («Не мячно височінь фіорітури / Міняти на Арібні недобігури?»), цікаву перекладацьку знахіАку, коли йдеться про шахові ходи, «відточені із вправністю гравера», — вогнерит (аналогія 3 дереворитами, мідеритами чи іншими естампами): «Гравців єАнає внутрішнє горіння, / I кожна партія — це вогнерит».

Як зазначалося вище, автор шахопоезій не байдужий до фонетичного слова. Звукописну стихію в розгляданих текстах можна спостерігати в найрізноманітніших виявах. Скажімо, шахосонет «Загуслі янтарі» $[8,32-33 ; 10,58]$ побудований переважно на омонімічних римах, де, наприклаА, у катренах маємо: ясен - іменник у родовому відмінку віА ясна (у першому рядку), в іншому рядку це прикметниково-присудкове слово, ще в іншому рядку - іменник у називному відмінку (Аерево); омонімічне пили - це і родовий відмінок однини іменника пила, і форми таких дієслів, як пити, пилити. У терцетах: варта - це й іменникове слово (сторожа) і прикметниковий присудок; омофонні суголосся

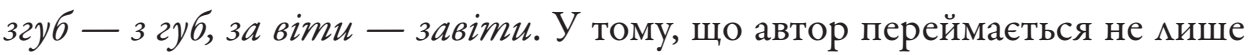
звучанням, а й змістовою наповненістю слова, можна пересвідчитися, хоч би зіставивши фінальні терцети цього ж сонета у збірках «Картатий материк» і «Негарантована мігрантіана».

Привертає увагу римування атракційних метатез у сонеті «Час ос» [8, 18-19]: сосна - насос, ось на - на ос; ялину - лину - ну, лиш гукнули; війною - Ною вій... Перестановку місцями римованих складів і слів відтінює чергування полів у розв'язку задачі, де білі в загрозі ходять спочатку на одне поле, потім на друге, а у варіантах послідовність полів змінюється на зворотну. Метатези шаховою мовою!

Мініпоема-складень «Ієрогліфічне» $[8,38]$ об’єднала два сонети-

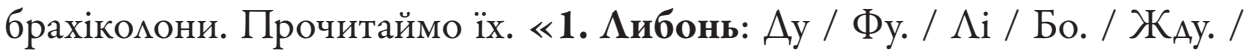
Зву, / ми- / бонь: / “Про- / це- / сій / по- / е- / зій!”»- «2. Щось ніби з “Книги Змін”: Ян / до / інь / мип. / ГАянь: / то - / тінь / вглиб. / ЖАе / рух / змін. / Ае / пруг, - / скін». Обидва тексти подано вертикацьно орієнтованими в просторі сторінок, що наслідує східні написи. А чорні фігури на діаграмі десятиходівки теж прямовисно згрупувалися на коромівському фланзі, наче ієрогліфи, виведені вправним каліграфом. Білих 
фігур мише Аві: крім короля, тура. Це мінімальна кількість, можлива в шаховій задачі. І вона підсилює маконізм обраної поетичної форми.

Автор не без певного ризику ускмаднює текстуру шахосонетів фразеологізмами. У першій частині цикму «Комп'ютерний Шумер» текст суцільно складається з них, що дало змогу згустити, здавалось би, непоєАнувані змістові барви, об'єАнавши їх іронічним колоритом [8, 22-24].

\section{1. Версія ідіоматична:}

В кривому Азеркалі стріла Амура

Розбима глека: ій немає спуску.

Узявши на арапа, часто й густо

I сміх і гріх у повному ажурі

Ані гу-гу, розводять шури-мури

Та мовмять гав. Бодай їм буде пусто!

На догад буряків... Аами капусти:
Розвісиш вуха - і пошиють в дурні.

Адамове ребро гра першу скрипку,

Встругнувши штуку, обдере як мипку.

Болюча струно! Варта гра свічок?» -

«Чи підАавати жару у вогонь?

Пани мої дрібнесенькі! Боронь

Вас Боже попадатись на гачок...».

Підзаголовок («Google-переклад на Ава мади») у розглядуваному циклі вказує на те, що текст іншого сонета має бути з прямим значенням слів. Але адамоверебро й тут не Арімає, вигадииво піАбурюючи свого ААама. Тому й у сонеті «2. Версія прагматична» не варто розраховувати на спрощену мову, бо «ВіА опіку ночей жадання крук / У за́пані несе розАратування». Ауже незвично спаяма обидва тексти шахова задача. Автор склав триходівку, в якій у варіантах жертвується білий ферзь. Коли чорний король його збиває, це сприймається як очікуване, пряме Аійство. А от коли король у відповідь раптом тікає від ферзя, то білі матують інакше - утвореною ферзем батареєю. Тобто в другому випадку маємо шахову ідіому. Побіжно зазначимо: цю сонетну задачу згодом було включено до антології «1000 шедеврів шахової композиції» $[1,210]$.

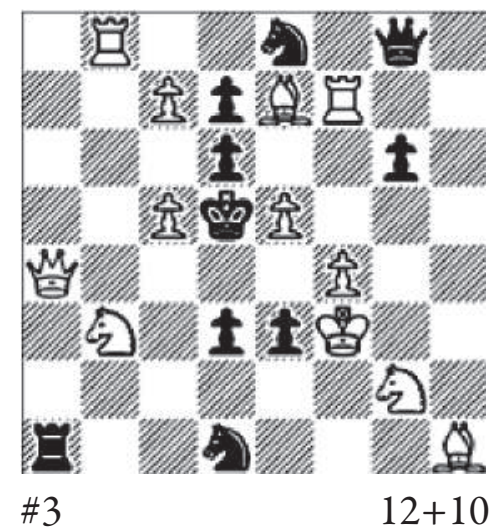

1.Kpg3! із загрозою: 2.K:e3+ Kpe6 3.Cd5\#; 1...Ф:f7 2.Фe4+! Kp:e4 3.Kh4\#, 2...Kpe6 3.e:d6\#!; 1...Кc3 2.Фc4+! Кр:с4 3.К:e3\#, 2...Крс6 3.c:d6\#!; 1...Kpe6 2.Q:d7+! Kp:d7 3.c8Ф\#, 2... Kp:f7 3.C:d6\#!, 2... Kpd5 3.K:e3\#. 
Надзвичайно скмадне завдання постало перед автором, коли він пірнув у версифікаційну стихію паліндрома. У паліндромії рівноправним співавтором $\epsilon$ рідна мова, ії невичерпні багатства й можливості, що Аають змогу вибудувати текст, прочитуваний однаково зАіва направо i навпаки. ВихіАною точкою паліндромного сонета-гротеску В. Капусти «Метаморфози теми Баха» (Ао речі, це чи не четвертий усього за рахунком сонет-паліндром в українській поезії) послужили, як довіАуємося з переднього слова до вірша, відвідини концерту струнного ансамблю. Тож налаштуймося на музичну хвимю:

\section{Ваджарт страждав}

I Ра віА арт се... Страдіварі

Тенетно гра. Жаргон тенет.

Тем ша́башу душа - Башмет.

Кураж ув еф, і фе вужа рук.

Віраж от стелі, мет Стожарів.

$\mathrm{Te}$ - кіп вік. Чим смичків пікет

Тебе корив? Вир - о! — кебет.

I рав... I Аар... Тс... ЕстраАі-в-арі.
Оно я мер во врем’я оно.

Аорога нуду? Нагород!

I, ноти раб у баритоні,

Аоганить мад альти нагод.

Вів цнот акорА оАр - ока тон цвів.

Токат гротеск - се торг. Так от.

$[8,36-37]$

Як пояснював поет, «рухи смичка туди - назад підказали сонетові форму паліндрома» $[8,69]$. Паліндромний настрій передається діаграмі. Білий ферзь альтовим смичком плавно рухається вгору-вниз наА декою шахівниці. При цьому смичок прокреслює маршрут у вигляді великої зірки, натякаючи на космічну природу шахів і музики. Недаремно в одному журнальному інтервю В. Капуста стверджував: «У шахів неземне коріння» $[5,56]$.

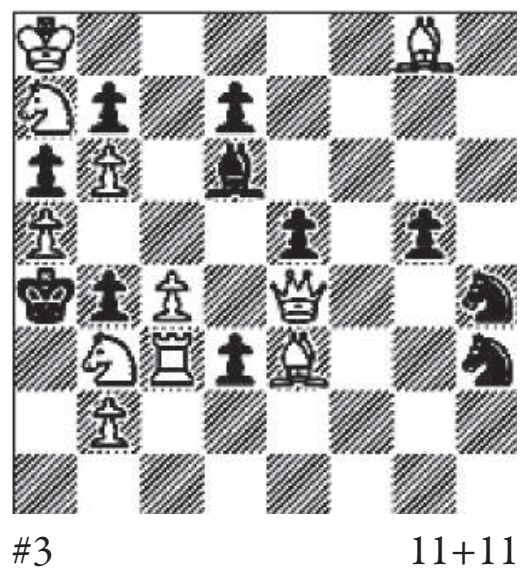

1.c5! із загрозою: 2.Tc1 i 3.Ta1\#; 1...d2 2.Фb1! d1Ф 3.Фa2\#, 2...b:c3

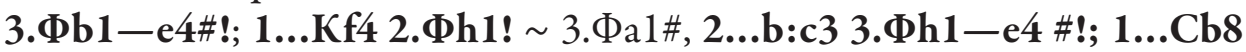

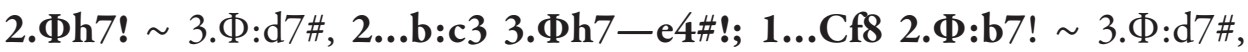
2...b:c3 3.Фb7-e4 \#!; 1...C:c5 2.C:c5 3.Ф:b4\#. 
Звернімо увагу на таку яскраву деталь. Перший і восьмий рядки тексту скмадаються з однакових мітер, розташованих суворо в тій самій послідовності. Порівняймо: «І Ра від арт се... Страдіварі» та «І рав... I дар... Тс... Естраді-в-арі». Мітери прочитуються як паліндром у зворотному напрямі та мають подвійне прочитання зАіва направо шляхом утворення нових слів, тобто спостерігаємо ще і явище панториміі. Таке поєднання паліндрома і панторими в українському мітературознавстві називають паціндромною панторимою $[2,64]$.

Панторима служить версифікаційною і композиційною основою шахового вінка сонетів «Рокірування. Зір гербарій» [8, 49-66; 10, 86-101]. Аумаю, панторимний вінок В. Капусти - унікальна з'ява не тільки в українській, а й у світовій поезіі. Нагадаємо, що панторима (віА

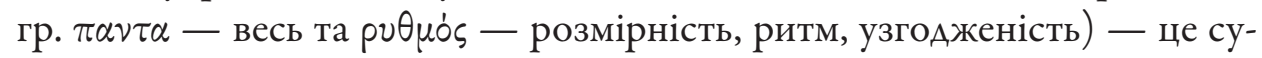
голосся, яке охоплює цілі рядки. Саме автор вінка вперше суцільно грунтує строфіку на панторимних версах. Про трудність такого римування говорить хоч би той факт, що в жодному з українських словників (і в переважній більшості відомих нам іншомовних) до тлумачення терміна панторима не подано ілюстративного матеріалу, де рядки римувацись би повністю. 3 огляду на це несподівана колізія виникца навіть у двотом-

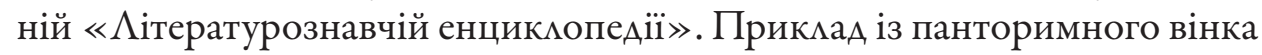
В. Капусти, як кажуть, із цьоту потрапив до їі 1-го тому в статті «Вінок сонетів» $[11: 1,187]$, проте стаття «Панторима» в 2-му томі $[11: 2,178]$ зберегла застаріку на той час ремарку: «Повністю заримованих віршових рядків із П[анторимою] не віднайдено». Автор «Рокірування» не здогадувався, що Аоля розкрила перед ним панторимну tabula rasa (про це він принагідно зізнався згодом), і рішуче взявся за роботу. В іншому випадку через різні «неофітські» перестороги могло б забракнути рішучості. Щось подібне, кажуть, трапимося з А. Ейнштейном. Коли видатного вченого запитали, як йому спала на думку ідея вибудувати теорію відносності, відповів цілком щиро: «Я не знав, що цього не можна робити. А інші знали».

В. Капуста пропонує нам цілий шерег римувань на зразок: «Ані просто Аиця остовпілі, грим» - «Аніпро. Столиця-остов. Пілігрим»; «Не мов гра - вірування воскурінню» - «Немов гравірування воску рінню»; «Аобі гроз - зява зиук. Аоба говіння» - «Добіг роззява з кук до баговіння». ВАасне, кожний перший рядок Аругого, третього та решти сонетів панторимні до прикінцевих рядків попереАніх віршів вінка і впевнено спрямовують читача до фінальної фази магістрацу.

Сюжет «Рокірування» просторово розвивається у Авох багатовекторних площинах - земній і космічній. Він не обмежений конкретним часом і точно означеними теренами. Аія, ніби нехтуючи закони віднос- 
ності, які відкрив Ейнштейн, зі стрімкістю, доступною мише метафорі, переноситься віА урочища Ківшар на Ворсклі до сузір'я Ківш (із допомогою сучасного радара), звідти - до Аніпра, віА Аніпра - Ао Єрусалима, трохи реального і трохи вигаданого міста («Куди веде Аніпрова первозванність, - / Не кода - коА, - в новий Єрусалим?»), Аалі - до Вавицонського царства («Колиб, овва, нам в пору Вавилона!» 3 панторимним відлунням: «Коли бовванам впору вави мона»), затим повертається через Чумацький Шиях до Ківшара й до Києва («Аніпро. Столицяостов»). Кого так стрімко несуть крима сюжету з краю в край, із сузір'я в сузір'я, з епохи в епоху? Маленьку грішну ^юдину. Аюдину з ії забобонами, упередженістю, погордою, байдужістю, безвір'ям («Безриб'я, як безвір'я, - без кмюча»), непослухом («Непоскуху пере́ступи і досвіА / Зі світу запроторюють у досвіт»). Ту мюдину, на яку обрушуються «сваволя міфів і глаголи притч ». Ми поступово пізнаємо їі. Це ж достеменно персонаж євангельської оповіАки про блудного сина (хоч прямо й не названого). Збірний персонаж - із багатьма обличчями і схожими домями. Той, хто ніяк не може ні розпцутати, ні розрубати гордіїв вузол власних проблем. Він потрапляє в різні перипетії та халепи, проходить часом крізь суворі випробування, про що читач довіАується Аише з коротких штришків, із якихось інформаційних скалок і друзок, поступово складаючи Амя себе більш-менш узагальнену картину. Зрештою, в читацькому серці зароджується співчуття до нього: чи повернеться він у Аім отця свого? і яким повернеться?..

Ао образу блудного сина автор чи не вперше наблизився в початковій редакції сонета «Вертлявість голчаного вушка» $[8,10]$, коли було «Приціли збито, і сурмкять хорти / Пораненому птаху місце збору». Тоді пролунала по-батьківському тепла засторога: «ПогорАа, сину мій, - відбиток волі / В спектаклі, де не спекатися ролі. / I світ, і світло всіх взяли на пушку». Потім син, що безпорадно блукає-тиняється, набиваючи гулі та синці в душевній напівтьмі, вирушає сторінками панторимного вінка. Спочатку у вигляді парочки закоханих (сонет 1), яка спостерігає «вселенську зав' язь кволих тіл і душ» із театральної гальорки (чи галери?! Бо «Гальорку мрії - на комет галери. / Серця прикуто до вериг чимдуж»). Потім - у постаті послушника-дзвонаря (сонет 2) на Охтир-горі («Азвонар не може дати одкоша / У пеменгу гріха ночам почвари»). «ВіАлунок подзвону», коли «метить дзвіниці стоммена ракета», передається іншим: «Щоб розгадати міді голосіння, / Торує Тори рав тропу терпіння, / Самітнику наметана верета» (3). А^е чи не забкукають, як інші персонажі, Тори рав і самітник? Бо ж «даний всім закон на всі віки: / Не розміняти мідь на срібняки». За ними промайнуть у сюжеті п’яний Аот із біблійного Содома (10), якісь галасливі голі просторіки - «давніх межиріч провина» (8), міфічний Iкар (11), 
що не Аослухався поради батька Аедала й, обпікши штучні крила, упав у морську пучину.

У якийсь момент у поле нашого зору потрапляє простак $і$ мудрагель, прибулий до Єрусалима (4). Він «В чужу турботу / Заходить мудрецем, земну скорботу / Несе до Пцач-стіни як вічний стрим». При цьому «позіхав, тамуючи нудоту / У будень-непробудень не пісним». Незважаючи на свою мегковажність і мляву мегковірність, наче «Готовий вік блукати він по світу / Старого і Нового Заповіту». Хто ж він такий? Наш земмяк. Авторові сонетного вінка несподівано відкривається прихований зміст назви міста Єрусалим: $є$ рус алим. Рус - русич, русин, а щодо алима (варіант: алім) то довідники стверджують, що слово, яке пізніше поширилось як ім'я Алім, у перекладі з арабської означає 'мудрещь', 'мудрий, 'mой, хто все знає'. Та окремі Ажерела засвідчують і єврейські корені слова [Аив.: 7]. Ао речі, Алим (Алім) співзвучне й сучасному поняттю, впровадженому в ізраїльській юриспруденції: олім, а повністю олім хадашим - нові репатріанти [Аив.: 6; 21]. Помітивши невипадкову єАність між русами та Єрусацимом, автор не замилувався їхньою мудрістю та критично-співчутливо поглянув на земляків, як і на решту блудних синів. А цей мінгво-містичний зв'язок спроєктовано на опорні ряАки панторимного тексту, що звучать своєрідним рефреном: «B’є рус-ацим із вір Єрусалим» - «В Єрусалимі звір: $є$ рус алим»; «Єрусалим ізвір $\epsilon \ldots$ рус - алим...»- « промовистий образно-смисловий манцюг із віАповідно означуваними домінантами, вираженими прийменниково-відмінковою формою іменника віра, формою наказового способу дієслова звірити, іменником ізвір (застаріле, Аіалектне: яр) та сполучниково-іменниковим компонентом ( $i+3$ вір - підклас ссавців). Чи $\epsilon$ шанс подолати звіра? У притаманній авторові нерозкодованій атракції він дає поетичну відповідь-підказку, де шукати порятунку: «Небалакучий - потрясіння плоть. / Де небораку жАе загроз гроза, / Небарно млється зацоз міз сльоза: / Не бескиди збирають - змиплий рот.» (13). «Неба!» - волає перший голос. «Ае небо?» - чи не з відчаю запитує інший. «Неба!» - підхоплює третій. «Небес!» - вислов юється спільне прагнення. I тепер кожний заблудлий має шанс по-новому осмислити зворотний шлях сина до батьківського Аому, де на нього, незважаючи ні на що, чекає отець. Атракція переміщається на кінці версів, укотре майже не приховуючи коду тексту: «У просині безсмертя - колосина. / Чи схоче, лежачи в грунтах, просина / Зі споду піднестися до господ? / Натомість - відцурання поворот. / Не гени в'яжуть - віри волосина. / Житейське море... Воскова росина.../ I крим купімь - у мітеплі марнот» (11). Коло сина - про сина сина! - сина! I ми вже не сумніваємося, про якого Сина насправді мова і до якого Отця прямує Він. 
Тимчасом жила на світі Аюдина, котра не плуталась і не плутала інших, сприймаючи як аксіому космічний масштаб буття, нерозривність зв'язку між Землею і Небом. Антитезою збірному персонажеві сонетного вінка входить у сюжет Григорій Сковорода, знаний у найближчому колі ще як Варсава. Вічний мандрівник спалахнув на монастирській Охтир-горі світмою зорею: «За постолами сходить мисль отаві: / Якщо не топчуть, мудрощі - вода. / Чумацький шлях. Ківшар. Сковорода. / ЗАороженість - на монастирській маві» (12). Після короткого відпочинку філософа тривають «прайм-тайми правослів'я в православ'ї...». 3 допомогою центону автор майже дослівно подає витяг із відомої праці філософа. «"В Єрусалимах не бкукай - сльота! / Потрібне нам дається без труда / I сереА вас стоїть...” Трактат - в заставі!». Ось і категорична порада нашого мислителя шукачам «ерусалимських» мегких відповідей на скцадні питання. А тепер: «На відкуп чи покути мислі? Тям. / ВіАповідай за все земним життям. / Звіряйся із Ковшем, що за радаром / Поверг мільйони міт в страсний цейтнот. / Та жоден відступ не минеться даром...». Не відступивши ні на крок оА своїх переконань і глибокої віри, Сковорода в передостанньому, чотирнадцятому, сонеті рушає своїм зоряним шияхом у бік Аніпра і «столиці-остова». «Тропа у твердь - тендітна вертикаль / Вітчизна пімігриму - магістраць, / Бо світ мовив, та не спіймав, Варсаво!». Попереду - похід крізь нічну темряву. «Як ночі змій оскалився триглаво, / Зорі тонка опора, — вертикац, — / Зенітом - у подвійний магістрам». Що ж, сюжет вінка добігає кінця. Та він буде неповний без завершального оркестрового звучання панторими у стилі tutti, коли водночас грають усі інструменти $[25,280]$. Саме панторимною формою римування зумовлено те, що п'ятнадцятий, магістральний, сонет вінка постає, по суті, у двох іпостасях. Аозволю собі навести тут повністю обидві фіналі:

$\alpha 15$

Ані - просто Аиця остовпілі, грим. Немов гравірування воску рінню. Аобіг роззява з кук до баговіння В Єрусалимі. Звір: є рус алим.

«Великому сьогодні - за малим», По чварі карлик долуча сумління. Імли вогнів ув течі коло: тінню $€$ рус, алим і звір... Єрусалим!

Коли бовванам впору вави мона, На трутня іскри жаль уз Рубікону. Аедам... - Ікар... Просина - околот.

За постолами сходить мисль отаві. Покров із речень виріс карі: от $€$ в ангелі йод вірок - вар, Варавво!

\section{$\beta 15$}

Аніпро. Столиця-остов. Пікігрим. Не мов гра - вірування воскурінню. Аобі гроз - з'ява змук. Аоба говіння. B’ $є$ рус-алим із вір Єрусалим.

Вели комусь: «О, годні замалим!» Почварі кар - лик долу, часу мління. I мливо гніву - втечі. Колотінню Єрусалим ізвір є, рус - алим.

Колиб, овва, нам! В пору Вавилона Натрутня і скрижаль. У зруб - ікону! Аедалі кар проси на око. $\Lambda$ от -

3 апостолами. Сходи тьми сльотаві По кров і зречень вир. Іскаріот Євангелій одвірок: варвар, Авво! 
Фіналей дві. Але сюжет не роздвоївся. Навпаки - міцніше сплів Аолі блудних синів і праведника. Ця художньо-образна цілісність досягнута й завдяки появі в магістралах анжамбеманів (у кожному по три), які притягли нові смислові відтінки в текстову тканину. Особливу роль відіграє завершальний стоп-кадр панторимного вінка шахосонетів, коли всі

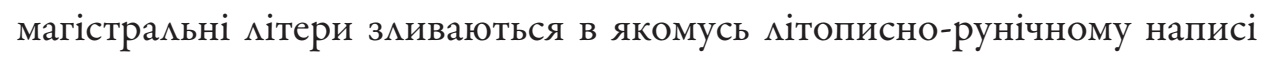
на монолітному тлі шахової діаграми $[8,66]$ :

$$
\begin{aligned}
& \text { Аніпростолицяостовпілігрим } \\
& \text { Немовгравіруваннявоскурінню } \\
& \text { Аобігроззявазлукдобаговіння } \\
& \text { Вєрусалимізвірєрусалим } \\
& \text { Великомусьогоднізамалим } \\
& \text { Почварікарликдолучасумління } \\
& \text { Імливогнівувтечіколотінню } \\
& \text { Єрусалимізвірєрусалим } \\
& \text { Колибовванамвпорувавилона } \\
& \text { Натрутняіскрижальузрубікону } \\
& \text { Аедалікарпросинаоколот } \\
& \text { Запостоламисходитьмисльотаві } \\
& \text { Покровізреченьвиріскаріот } \\
& \text { Євангелійодвірокварваравво! }
\end{aligned}
$$

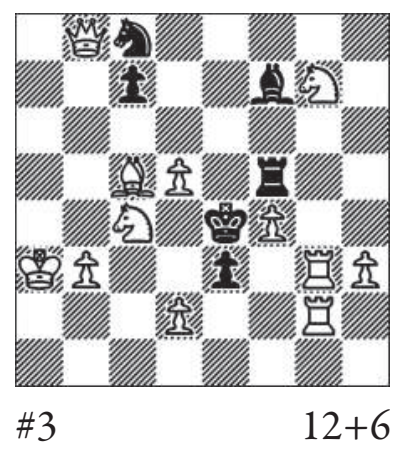

1.Фb5! із загрозою: 2.d3+ Kp:d3 a 3.T:e3\# $A, 2 . . . \mathrm{Kp}: \mathbf{d} 5$ b 3.K:e3\# $B$, 2..Kp:f4 $c$ 3.C:e3\# $C$; 1...Kpd3 a 2.K:e3+ $B$ Kpe4 3.Фc4\#; 1..Kp:d5 b 2.C:e3+ $C$ Kре43.Ф:f5\#, 2...c5 3.Фb7\#; 1...Kp:f4 $c$ 2.T:e3 $A$ i 3.Tg4\#, 2...Tg5/Ch5 3.Tf2\#/3.Ke6\#.

Задача на діаграмі $\epsilon$ своєрідною шаховою компонентою сонетного вінка. Варіанти розв'язку (захисні рухи чорного короля на перших хоАах: $1 \ldots a, b, c$; і другі ходи білих фігур: $2 . A, B, C)$ відповідають віршовим рядкам, із яких складаються чотирнадцять сонетів. Хід загрози в задачі, наче магістрац, зосереджує згадані шахові рухи в одному варіанті, перемістивши ї на Аругі ходи чорних і треті (матувальні) ходи білих $(2 \ldots a, b, c$ i 3. $A \#, B \#, C \#)$. 
Слово і старовинна гра вкотре запрагнули гармонійного синтезу в шахопоезіі. I, здається, таки досягли свого.

Отже, шахопоетична творчість із появою книжок В. Капусти «Картатий материк» та «Негарантована мігрантіана» постаца новою оригінальною сторінкою на теренах української візуалістики. Культивуючи сонетний текст, автор спромігся на суголосне вираження іАеї в шаховокомпозиційному Аискурсі, який явАяє собою розв' язок шахової задачі та разом із власне текстовою структурою становить цілісний мистецький синтез.

\section{МITEPATУPA}

1. Владимиров Я. 1000 шедевров шахматной композиции. Москва: Астрель - АСТ, 2005.543 с.

2. Аунь H. Мовний експеримент у зоровіршуванні (переважно в шахопоезії та паАіндроміiі) // Слово і Час. 2010. № 1. С. 57-66.

3. Етимологічний словник української мови: У 7 т. Київ: Наукова думка, 2006. Т. 5. 704 с. 4. Жулинський М. Аух, що єАнається зі світом інших // Мойсієнко А. Вибране: Поезії і переклади / Передм. акад. М. Г. Жулинського. Київ: Фенікс, 2006. С. 3-9.

5. Захарченко Г. У шахів неземне коріння // Надзвичайна ситуація. 2003. №1. С. 56-57.

6. Інформація... URL:https://www.gov.il/ru/departments/ministry_of_aliyah_and_integration

7. Історія походження імені А^iм. URL: https://yakzvaty.com.ua/alim-znachennya-ipohodzhennya-imeni/

8. Капуста В. Картатий материк: Веб-сайтська історія: Сонетний гамбіт. Київ: Видавничий Аім Амитра Бураго, 2003. 72 с.

9. Капуста B. Шахові образи в поетичному контексті // Наукові записки. Серія: Філологічні науки (мовознавство) / Кіровоградський держ. пед. ун-т. ім. В. Винниченка. КіровограА, 2013. Вип. 117. С. 29-35.

10. Капуста В. Негарантована мігрантіана: 100 і один мандрований сонет. Київ: Видавничий дім Амитра Бураго, 2020. 112 с.

11. Капуста В. [Шахосонет] // Українське слово. 1998. 30 грудня.

12. Аітературознавча енциклопедія: У 2 т. / Автор-укмадач Ю. І. Ковалів. Київ: ВЦ «Академія», 2007.

13. Ауговик М. Зорова поезія: від футуризму Михайля Семенка до паліндромних братчиків Аітературного гурту «ГЕРАК АIТ» // САово і Час. 2014. № 2. С. 33-44.

14. Аучук I. Мистецтво поетичне в Аискурсі української Аірики та письменницької критики. $\Lambda$ ьвів - Київ. 2012. 444 с.

15. Мойсієнко А. Шахопоезія. Париж -

16. Мойсієнко А. Традиції модерну і модерн традицій. Київ - Ужгород: Патент, 2001. 80 с.

17. Мойсієнко А. Зоровірші Миколи Ауговика на тлі української візуальної поезії від Аавнини до сьогодні // Київ. 2007. № 7-8. С. 182-185.

18. Мойсієнко А. Фінологічні студії. Київ - Умань, 2015.367 с.

19. Назаренко T. Поезографія: сучасна зорова поезія українською мовою. Київ. 2005. 204 с.

20. Никифорова А. Остроконечный круг. Київ: Видавничий Аім Амитра Бураго, 2020. 64 с.

21. Нове слово: олім. URL: https://newslab.ru/article/168195

22. Сорока M. Зорова поезія й українська мітература // Україна. 2000. № 10. С. 40—41. № 11. С. 44-45.

23. Сулима М. Книжиця у семи розділах. Київ: Фенікс, 2006. 424 с.

24. Шахопоезія: Хорхе Ауї Борхес. Ораціо Аміл Мейлан / 3 іспанської переклали Віктор Капуста і Микола Аябах // Всесвіт. 2009. № 7-8. С. 56-61.

25. Юикевич Ю. Музика. Словник-довідник. Тернопіль: Навчальна книга - БогАан, 2003. 352 c.

Отримано 3 березня 2021 р. 


\section{REFERENCES}

1. Vladimirov, Ya. (2005). 1000 shedevrov shakhmatnoi kompozitsii. Moscow: Astrel - AST. [in Russian]

2. Dun, N. (2010). Movnyi eksperyment u zorovirshuvanni (perevazhno v shakhopoezii ta palindromii). Slovo i Chas, 1, 57-66. [in Ukrainian]

3. Etymolohichnyi slovnyk ukrainskoi movy. (2006). (Vol. 1-7; Vol. 5). Kyiv: Naukova dumka. [in Ukrainian]

4. Zhulynskyi, M. (2006). Dukh, shcho yednaietsia zi svitom inshykh. In Moisiienko, A. Vybrane: Poezii i pereklady (pp. 3-9). Kyiv: Feniks. [in Ukrainian]

5. Zakharchenko, H. (2003). U shakhiv nezemne korinnia. Nadzvychaina sytuatsiia, 1, 56-57. [in Ukrainian]

6. Informatsiia... https://www.gov.il/ru/departments/ministry_of_aliyah_and_integration [in Ukrainian]

7. Istoriia pokhodzhennia imeni Alim. https://yakzvaty.com.ua/alim-znachennya-ipohodzhennya-imeni/ [in Ukrainian]

8. Kapusta, V. (2003). Kartatyimateryk: Veb-saitska istoriia: Sonetnyi hambit. Kyiv: Vydavnychyi dim Dmytra Buraho. [in Ukrainian]

9. Kapusta, V. (2013). Shakhovi obrazy v poetychnomu konteksti. Naukovi zapysky. Seriia: Filolohichni nauky (movoznavstvo), 117, 29-35. [in Ukrainian]

10. Kapusta, V. (2020). Neharantovana mihrantiana: 100 i odyn mandrovanyi sonet. Kyiv: Vydavnychyi dim Dmytra Buraho. [in Ukrainian]

11. Kapusta, V. (1998, December 30). [Shakhosonet]. Ukrainske slovo. [in Ukrainian]

12. Kovaliv, Yu. I. (Ed.) (2007). Literaturoznavcha entsyklopediia. (Vol. 1-2). Kyiv: VTs "Akademiia". [in Ukrainian]

13. Luhovyk, M. (2014). Zorova poeziia: vid futuryzmu Mykhailia Semenka do palindromnykh bratchykiv literaturnoho hurtu "HERAKLIT". Slovo i Chas, 2, 33-44. [in Ukrainian]

14. Luchuk, I. (2012). Mystetstvo poetychne v dyskursi ukrainskoi liryky ta pysmennytskoi krytyky. Lviv - Kyiv. [in Ukrainian]

15. Moisiienko, A. (1997). Shakhopoeziia. Paris — Lviv — Zwickau. [in Ukrainian]

16. Moisiienko, A. (2001). Tradytsii modernu i modern tradytsii. Kyiv — Uzhhorod: Patent. [in Ukrainian]

17. Moisiienko, A. (2007). Zorovirshi Mykoly Luhovyka na tli ukrainskoi vizualnoi poezii vid davnyny do sohodni. Kyiv, 7-8, 182-185. [in Ukrainian]

18. Moisiienko, A. (2015). Filolohichni studii. Kyiv —Uman. [in Ukrainian]

19. Nazarenko, T. (2005). Poezohrafiia: suchasna zorova poeziia ukrainskoiu movoiu. Kyiv. [in Ukrainian]

20. Nikiforova, L. (2020). Ostrokonechnyi krug. Kyiv: Vydavnychyi dim Dmytra Buraho. [in Russian]

21. Nove slovo: olim. https://newslab.ru/article/168195 [in Ukrainian]

22. Soroka, M. (2000). Zorova poeziia y ukrainska literatura. Ukraina, 10, 40-41; 11, 44-45. [in Ukrainian]

23. Sulyma, M. (2006). Knyzhytsia u semy rozdilakh. Kyiv: Feniks. [in Ukrainian]

24. Borges, J. L., \& Meilan, H. A. Shakhopoeziia. (2009). (Kapusta, V., \& Liabakh, M., Trans.). Vsesvit, 7-8, 56-61. [in Ukrainian]

25. Yutskevych, Yu. (2003). Muzyka. Slovnyk-dovidnyk. Ternopil: Navchalna knyha - Bohdan. [in Ukrainian] 
Anatolii MOISIIENKO, doctor of philology, professor

Taras Shevchenko National University of Kyiv

14 Taras Shevchenko Boulevard, Kyiv, 01601

e-mail:anmoj@ukr.net

ORCID: https://orcid.org/0000-0002-7856-2746

\section{ARTISTIC SYNTHESIS IN CHESS SONNET}

The article focuses on one of the visual types of syncretic poetry - chess poems. Years ago Anatolii Moisiienko initiated the chess poetry genre in Ukrainian literature; in a number of critical papers, he presented the specifics of construction and functioning of such artistic structures, which are basically characterized by the symbiosis of proper poetry and chess composition. In this article, the author uses Viktor Kapusta's books of poems "The Checkered Continent" and "Unguaranteed Migrations" to analyze the chess sonnets of the poet who added a new page to the history of Ukrainian visual literary art by proposing a peerto-peer combination of a strictly structured literary form and a chess problem. The aim is to conceptualize the figurative and compositional relations within the sonnet structure itself, which relies on the artistic palette of the chess game, with its diversity of geometric abstractions, local mise-en-scènes of unpredictable theatrical performances played out on the chessboard by wooden pieces - or on the chessboard of readers' imagination. Attention is drawn to the transformational peculiarities of the sonnet line, read in a palindromic and pantorhymic way. The pantorhyme is the versificational and compositional basis for the chess sonnet sequence "Castling. A Herbarium of Stars", which is analyzed here with regard to the transposition of some characteristics to the realm of chess composition. A diagrammed chess problem becomes a specific chess component of a sonnet sequence, where, for example, the variants of the solution (Black's defensive moves and White's attacking responses) correspond to the poetic lines making up the fourteen sonnets whereas the problem's threat, like a principal poem, concentrates all the mentioned chess movements in a single variant.

Keywords: chess poetry, chess sonnet, palindromic sonnet, pantorhymic sequence of chess sonnets, occasionalism. 